University of Nebraska - Lincoln

DigitalCommons@University of Nebraska - Lincoln

Faculty Papers and Publications in Animal

Science

Animal Science Department

1993

\title{
Environmental Effects on Neonatal Mortality of Beef Calves
}

S. M. Azzam

University of Nebraska-Lincoln

J. E. Kinder

University of Nebraska-Lincoln, kinder.15@osu.edu

Merlyn K. Nielsen

University of Nebraska-Lincoln, mnielsen1@unl.edu

L. A. Werth

University of Nebraska-Lincoln

K. E. Gregory

Roman L. Hruska U.S. Meat Animal Research Center, USDA-ARS, Clay Center, NE

See next page for additional authors

Follow this and additional works at: https://digitalcommons.unl.edu/animalscifacpub

Part of the Animal Sciences Commons

Azzam, S. M.; Kinder, J. E.; Nielsen, Merlyn K.; Werth, L. A.; Gregory, K. E.; Cundiff, Larry V.; and Koch, R. M., "Environmental Effects on Neonatal Mortality of Beef Calves" (1993). Faculty Papers and Publications in Animal Science. 481.

https://digitalcommons.unl.edu/animalscifacpub/481

This Article is brought to you for free and open access by the Animal Science Department at DigitalCommons@University of Nebraska - Lincoln. It has been accepted for inclusion in Faculty Papers and Publications in Animal Science by an authorized administrator of DigitalCommons@University of Nebraska - Lincoln. 


\section{Authors}

S. M. Azzam, J. E. Kinder, Merlyn K. Nielsen, L. A. Werth, K. E. Gregory, Larry V. Cundiff, and R. M. Koch 


\title{
Environmental Effects on Neonatal Mortality of Beef Calves ${ }^{1}$
}

\author{
S. M. Azzam*, J. E. Kinder*, M. K. Nielsen*, L. A. Werth*, \\ K. E. Gregory ${ }^{\dagger}$, L. V. Cundiff ${ }^{\dagger}$, and R. M. Koch* \\ *Department of Animal Science, University of Nebraska, Lincoln 68583-0908 and \\ ${ }^{\dagger}$ Roman L. Hruska U.S. Meat Animal Research Center, \\ ARS, USDA, Clay Center, NE 68933
}

\begin{abstract}
Calving records from 1969 to 1989 from the Roman L. Hruska U.S. Meat Animal Research Center were used to investigate how climatic conditions, in addition to dystocia, age of dam, size of calf, and sex affect calf survival from birth to $1 \mathrm{wk}$ of age. Data were analyzed separately for cows calving with $(\mathrm{n}=11,094)$ or without $(\mathrm{n}=72,187)$ dystocia. Neonatal mortality was described by a logit model and parameters were estimated by maximum-likelihood procedures. Calves born to cows with dystocia were five times as likely to die neonatally than calves born without assistance. Of all calves that died, $43.6 \%$ were
\end{abstract}

born with difficulty. Of these calves, survival was lowest for those that were small relative to their genetic group, sex, and age of dam. Large calves had markedly increased mortality only when born to 2-yr-old dams. Average ambient temperature and precipitation on day of calving affected survival nonlinearly and the magnitude of the effect depended on age of dam, sex and size of calf, and dystocia incidence. Calves born to 2-yr-old cows were more susceptible to severe weather conditions than calves born to older cows. The negative effect of precipitation on survival increased with decreasing temperature.

Key Words: Beef Cows, Neonatal Mortality, Survival, Dystocia, Birth Weight, Climate

J. Anim. Sci. 1993. 71:282-290

\section{Introduction}

Increasing the proportion of calves that survive to weaning is of utmost economic importance. There are approximately $32,958,000$ beef cows in the United States (USDA-ERS, 1989), of which approximately $51 \%$ or $16,809,000$ are in states with moderate to cold winters. Thus, approximately $15,128,100$ beef calves are born (assuming a conception rate of $90 \%$ ) in an environment in which cold stress is a concern. Total neonatal mortality has been estimated to be approximately 9\% (Cundiff et al., 1982), with approximately $7 \%$ of this mortality attributable to cold stress (Bellows et al., 1987; 6.9\%). Therefore, the calf losses during a single year, due to cold stress, could be approximately $\mathbf{9 5 , 0 0 0}$.

The purpose of this study was to investigate how climatic conditions, in addition to dystocia, age of dam, size of calf, and sex, affect calf survival from birth to 1 wk of age.

\footnotetext{
${ }^{1}$ Published as Paper no. 9966, Journal Ser., Nebraska Agric. Res. Div., Univ. of Nebraska, Lincoln 68583-0908.

Received May 1, 1992.

Accepted September 15, 1992.
}

\section{Data}

Data on calf mortality from birth to weaning came from several experimental projects at the Roman L. Hruska Meat Animal Research Center: 1) the germ plasm evaluation program, excluding Cycle III Phases IV and V (Cundiff et al., 1988); 2) the germ plasm utilization project (Gregory et al., 1988a); 3) the twinning project (Gregory et al., 1988b); 4) the heterosis retention project (Koch et al., 1985); 5) the genetic variation study (Cundiff and Gregory, 1982); and 6) the Hereford selection experiment (Buchanan et al., 1982). Genetic effects on calf survival have been reported from some of these projects (Gregory et al., 1978a,b, 1990, 1991; Notter et al., 1978; Cundiff et al., 1986). In addition, calves born to cows not included in a specific project were included in the present study. The total number of records was 97,161.

The data were edited to include only calves born at the Research Center from spring of 1969 to spring of 1989; the majority of calves were born in the spring. Calves that were stillborn, deformed, aborted, injured, slaughtered for experimental reasons, or had a recorded birth weight of less than $10 \mathrm{~kg}$ were deleted from the data set. Calves classified as stillborn (44 
calves) were deleted because the calf was assumed dead before parturition and the death should, therefore, not be attributed to any effects of weather. However, calves classified as dead at birth or dead soon after birth were included in the data set. After editing the data, the number of calves that had complete records was 90,087 . Of the calves, 5,763 (6.4\%) died within 1 wh of age, 2,545 (2.8\%) died between $1 \mathrm{wk}$ and weaning, $889(1 \%)$ were sold before weaning, and $80,890(90 \%)$ were weaned. Before analyzing the data, 2,802 calves with Bos indicus inheritance were also eliminated because of the relatively low numbers and because they have higher mortality rates under cold, windy, and wet conditions than Bos taurus calves (Josey et al., 1987).

Daily observations of weather conditions at the Research Center were compiled by the National Climatic Data Center, Asheville, NC and included minimum and maximum ambient temperature, amount, and type (rain or snow) of precipitation. Data on wind speed were not available. In the analysis, average daily ambient temperature was calculated as the mean of the minimum and maximum temperature. Amount of daily precipitation measured for snowfall was the amount of water in the snow and not the depth of the fallen snow.

\section{Statistical Analysis}

Parameter Estimation. Data on neonatal mortality (birth to $1 \mathrm{wk}$ of age) were described by logit models with parameters estimated by maximum-likelihood procedures (SAS 1985; CATMOD procedure). Maximum-likelihood procedures were used because too many subclasses had $0 \%$ mortality rate. The data were divided into categories (subclasses) determined by the class variables in the linear model specified for each analysis. In order to get convergence of the estimates and to get reasonable standard errors of the estimates, levels of factors (variables) in the linear model that occurred less than five times in combinations with levels of other factors were deleted.

The purpose of the study was not to estimate breed effects on neonatal survival, and, therefore, the breed proportions in the calves were not included in the model describing neonatal survival. Instead, a birth weight variable was created to describe whether a calf was light or heavy compared with the average calf of the same sex born to the same type of cow. Birth weight was thus expressed in terms of standard deviations from the mean birth weight for the sex $x$ age of dam $\times$ genetic selection line or breed composition sub-category. The seven birth weight categories (BWT) were $<-1.5,-1.5$ to $-1.0,-1.0$ to $-.5,-.5$ to .5 , .5 to $1.0,1.0$ to 1.5 , and $>1.5$ standard deviations. The proportion of calves expected to be in these categories, based on a normal distribution of birth weights, are $.0668, .0919, .1498, .3830 .1498, .0919$, and .0668, respectively.
After the initial editing, the data were divided into two sets by dystocia score. The first set (referred to as no dystocia) included calves born without assistance, with the assistance of pulling by hand, or of pulling with a calf puller but the attendant may actually have been able to pull the calf by the hand. The second set (referred to as dystocia) included all other calving situations.

The Logistic Linear Model. Both sets of data were described by the same logistic linear model but parameters were estimated independently for the two sets of data. The model describing survival from birth to 1 wk of age $\left(P_{n}\right)$ was as follows:

$$
P_{n}=\left(1+e^{z_{j k l m n}}\right)^{-1},
$$

where

$$
\begin{aligned}
z_{j k l m n}= & \mu+y_{j}+s_{k}+a_{l}+b_{m}+\beta_{1} X_{1}+\beta_{2} X_{1}^{2}+\beta_{3} X_{2} \\
& +\beta_{4} X_{2}^{2}+\beta_{4} X_{1} X_{2}+\beta_{5} X_{1}^{2} X_{2}+\beta_{6} X_{1} X_{2}^{2}+e_{j k l m n}
\end{aligned}
$$

and

$$
\begin{aligned}
\mu= & \text { overall mean, } \\
y_{j}= & \text { effect of the } j^{t h} \text { year, } \\
s_{k}= & \text { effect of the } k^{t h} \text { sex, } \\
a_{l}= & \text { effect of the } t^{t h} \text { age of dam, } \\
b_{m}= & \text { effect of the } m^{t h} \text { birth weight category } \\
& \text { (BWT), } \\
\beta_{i}= & \text { partial regression coefficients, } \\
X_{1}= & \text { average ambient temperature (C) on day of } \\
& \text { birth, } \\
X_{2}= & \text { amount of precipitation (millimeters) on } \\
& \text { day of birth, and } \\
e_{j k l m n}= & \text { random error associated with the } n^{t h} \text { cell, }
\end{aligned}
$$

as well as all possible two-way interactions between sex of calf, age of dam, and birth weight category. Sex of calf was coded as bull, heifer, or steer. The decision to castrate a bull calf depended on the experimental project. Age of dam at calving was classified as 2-yr-old, 3-yr-old, and older cows.

After editing to assure convergence and reasonable precision, a total of 72,187 calves were included in the data set of calves that had not experienced dystocia and 11,094 records were in the data set of calves born with dystocia.

Marginal Means. Marginal means (MM), equivalent to least squares means obtained when parameters are estimated by least squares procedures, were obtained by multiplying the vector of parameter estimates $(\boldsymbol{\theta})$ with vectors ( $\mathbf{k})$ describing the estimable functions:

$$
\mathrm{MM}=\mathrm{k}^{\prime} \theta
$$

Standard errors (SE) of the marginal means were calculated by taking the square root of the product 
Table 1. Chi-square tests of the variables in the maximum likelihood analysis of neonatal mortality (birth to $1 \mathrm{wk}$ )

\begin{tabular}{|c|c|c|c|c|c|}
\hline \multirow[b]{2}{*}{ Source } & \multirow[b]{2}{*}{$\mathrm{df}$} & \multicolumn{2}{|c|}{ No dystocia } & \multicolumn{2}{|c|}{ Dystocia } \\
\hline & & Chi-square & $P^{\mathbf{a}}$ & Chi-square & $P^{\mathrm{a}}$ \\
\hline Intercept & 1 & 5,440 & .0001 & 827 & .0001 \\
\hline Birth year & 20 & 273 & .0001 & 273 & .0001 \\
\hline Sex & 2 & 146 & .0001 & 51 & .0001 \\
\hline Age of dam (AOD) & 2 & 141 & .0001 & 17 & .0002 \\
\hline Birth wt category ${ }^{b}$ (BWT) & 6 & 154 & .0001 & 128 & .0001 \\
\hline $\mathrm{AOD} \times \mathrm{BWT}$ & 12 & 63 & .0001 & 31 & .0020 \\
\hline Temperature $(\mathrm{T})$ & 1 & 111 & .0001 & 4 & .0497 \\
\hline $\mathrm{T} \times \mathrm{T}^{\mathrm{c}}$ & 1 & 17 & .0001 & 5 & .0216 \\
\hline Precipitation (PCP) & 1 & 63 & .0001 & - & - \\
\hline $\mathrm{PCP} \times \mathrm{PCP}$ & 1 & 13 & .0003 & - & - \\
\hline $\mathbf{T} \times \mathbf{P C P}$ & 1 & 22 & .0001 & - & - \\
\hline $\mathbf{T} \times \mathrm{PCP} \times \mathrm{PCP}$ & 1 & 10 & .0019 & - & - \\
\hline
\end{tabular}

obtained from pre- and post-multiplying the variancecovariance matrix ( $\mathbf{V}$ ) of the estimates with the vector (k) describing the estimable functions:

$$
\mathrm{SE}=\sqrt{\mathrm{k}^{\prime} \mathrm{Vk}} \text {. }
$$

The marginal means of the dependent variable in the analysis were then converted to marginal means of mortality rate (MR) by the logistic cumulative distribution function:

$$
\mathrm{MR}=\frac{1}{1+e^{-\mathrm{MM}}} .
$$

Approximate $95 \%$ confidence limits (CL) for MR were obtained by inserting MM plus or minus 1.96 (based on a $t$-distribution with large degrees of freedom) times the SE into the same function (Azzam et al., 1989):

$$
\mathrm{CL}=\frac{1}{1+e^{-(\mathrm{MM} \pm 1.96 \mathrm{SE})}} .
$$

\section{Results}

Effects of Dystocia, Sex of Calf, and Age of Dam. Parameters were estimated after nonsignificant effects had been dropped from the initial model. The chisquare tests of the variables in the model are in Table 1 and the parameter estimates are in Table 2 . Marginal means of neonatal mortality were calculated using [1] and [3]; the values for temperature and precipitation were the average values for all calves born. Thus, all marginal means were adjusted to a $9.77^{\circ} \mathrm{C}$ ambient temperature and a $2.35 \mathrm{~mm}$ of precipitation. For example, the marginal mean of mortality rate (MR) for a bull calf born without dystocia was calculated as follows:

$$
\begin{aligned}
\mathrm{MM}= & 2.843-.357+.05251(9.77)-.001(9.77)^{2} \\
& -.069116(2.35)+.00105(2.35)^{2} \\
& +.002869(9.77)(2.35) \\
& -.000048(9.77)(2.35)^{2} \\
= & 2.81
\end{aligned}
$$

and

$$
\begin{aligned}
\mathrm{MR} & =\frac{1}{1+e^{2.81}} \\
& =.06 .
\end{aligned}
$$

Sex of calf did not interact with age of dam or birth weight category. Bull calves had the highest mortality rates even when dystocia and relative size of the calf (BWT) was accounted for. The estimates were .24 and .06 for bull calves born with and without dystocia, respectively. The same estimates for steers were .16 and .03 , respectively. This does not imply a positive effect of castration on survival. Calves selected at birth to be castrated were, for some reason, less likely to die during the 1st wk of life. In this study, this could be a genetic effect in that calves selected to be castrated were crossbred calves. The mortality rate for heifer calves born to cows with or without dystocia was .21 and .04, respectively.

The interaction of BWT and age of dam was the only significant interaction in the model (Table 1 ). The marginal means for the two sets of data (no dystocia, dystocia) are shown in Figure 1. Optimal survival occurred when calves were of moderate size. Small calves born to cows with dystocia had the highest mortality rates. There was a tendency for 
small calves born to 2-yr-old cows with dystocia to have a lower mortality rate than calves of similar size born to older cows with dystocia. This could be explained by possible preferential care of the 2-yr-olds. However, the numbers of calves in these extreme categories were not large enough for the differences to be significant.

When cows did not experience dystocia (Figure 1; lower three lines), calf mortality decreased with age of cow. The lowest mortality rate of calves born to 2-yr-old cows without dystocia (4.1\%) occurred when calves were .5 to $1 \mathrm{SD}$ below mean BWT. The lowest mortality rate of calves born to 3 -yr-old cows without dystocia $(2.0 \%)$ occurred when calves were .5 to $1 \mathrm{SD}$ below mean weight. However, the estimated mean mortality rates for calves born to 3-yr-old cows did not differ significantly (based on overlapping confidence intervals) for BWT in the range of -1 to $>1.5 \mathrm{SD}$. The lowest mortality rate of calves born to older cows without dystocia (2.0\%) occurred when calves were within -.5 to $1.5 \mathrm{SD}$ of the mean weight. However, only when calves were $<-1.5 \mathrm{SD}$ of average weight was the mortality rate significantly higher.

Effects of Temperature and Precipitation. Average ambient temperature on the day of birth had a curvilinear effect on the logarithm of the odds of survival (and not on survival itself; for interpretation of regression parameters in logit models see Pindyck and Rubinfeld, 1981). Precipitation affected survival only in calves born without dystocia. A likely explanation for this difference is that cows that required extensive assistance in calving would be brought under roof and the calf would not be exposed to the precipitation. Survival of calves born without dystocia was, in addition to being affected by precipitation and temperature separately, also affected by the interaction of precipitation and temperature. Graphing the functions

Table 2. Estimates of the parameters ${ }^{a}$ in the logistic linear model describing neonatal mortality

\begin{tabular}{|c|c|c|c|c|}
\hline \multirow[b]{2}{*}{ Variable } & \multicolumn{2}{|c|}{ No dystocia } & \multicolumn{2}{|c|}{ Dystocia } \\
\hline & Estimate & SE & Estimate & SE \\
\hline Intercept & 2.843 & .039 & 1.312 & .046 \\
\hline \multicolumn{5}{|l|}{ Sex } \\
\hline Bull & -.357 & .030 & -.232 & .035 \\
\hline Heifer & .044 & .028 & -.039 & .036 \\
\hline Steer & .313 & .038 & .271 & .044 \\
\hline \multicolumn{5}{|l|}{$A O D \times B^{b} T^{b}$} \\
\hline $2 \mathrm{yr},<-1.5 \mathrm{SD}$ & -.562 & .139 & -.499 & .177 \\
\hline $2 \mathrm{yr},-1.5$ to $-1.0 \mathrm{SD}$ & -.135 & .124 & .245 & .151 \\
\hline $2 \mathrm{yr},-1.0$ to $-.5 \mathrm{SD}$ & -.014 & .097 & 639 & .105 \\
\hline $2 \mathrm{yr},-.5$ to $.5 \mathrm{SD}$ & -.295 & .061 & .398 & .059 \\
\hline $2 \mathrm{yr}, .5$ to $1.0 \mathrm{SD}$ & -.639 & .102 & .349 & .078 \\
\hline $2 \mathrm{yr}, 1.0$ to $1.5 \mathrm{SD}$ & -.280 & .171 & .329 & .010 \\
\hline $2 \mathrm{yr},>1.5 \mathrm{SD}$ & -.798 & .229 & -.265 & .089 \\
\hline $3 \mathrm{yr},<-1.5 \mathrm{SD}$ & -.709 & .112 & -1.348 & .242 \\
\hline $3 \mathrm{yr},-1.5$ to $-1.0 \mathrm{SD}$ & -.031 & .122 & -.032 & .233 \\
\hline $3 \mathrm{yr},-1.0$ to $-.5 \mathrm{SD}$ & .552 & .119 & .436 & .186 \\
\hline $3 \mathrm{yr},-.5$ to $.5 \mathrm{SD}$ & .283 & .072 & .420 & .108 \\
\hline $3 \mathrm{yr}, .5$ to $1.0 \mathrm{SD}$ & .267 & .119 & .196 & .140 \\
\hline $3 \mathrm{yr}, 1.0$ to $1.5 \mathrm{SD}$ & .061 & .146 & -.034 & .152 \\
\hline $3 \mathrm{yr},>1.5 \mathrm{SD}$ & -.157 & .167 & -.043 & .137 \\
\hline$>3 \mathrm{yr},<-1.5 \mathrm{SD}$ & -.473 & .068 & -1.047 & .199 \\
\hline$>3 \mathrm{yr},-1.5$ to $-1.0 \mathrm{SD}$ & .228 & .078 & -.456 & .177 \\
\hline$>3 \mathrm{yr},-1.0$ to $-.5 \mathrm{SD}$ & .498 & .069 & .142 & .149 \\
\hline$>3 \mathrm{yr},-.5$ to $.5 \mathrm{SD}$ & .711 & .052 & .135 & .089 \\
\hline$>3 \mathrm{yr}, .5$ to $1.0 \mathrm{SD}$ & .603 & .078 & .499 & .139 \\
\hline$>3 \mathrm{yr}, 1.0$ to $1.5 \mathrm{SD}$ & .572 & .098 & .016 & .126 \\
\hline$>3 \mathrm{yr},>1.5 \mathrm{SD}$ & .318 & .101 & -.079 & .113 \\
\hline Temperature ( $\mathrm{T}$ ) & .052510 & .004988 & .0111302 & .0056713 \\
\hline $\mathrm{T} \times \mathrm{T}$ & -.001000 & .000240 & -.0006300 & .0002800 \\
\hline Precipitation (PCP) & -.069116 & .008732 & - & - \\
\hline$P C P \times P C P$ & .001050 & .000290 & - & - \\
\hline $\mathrm{T} \times \mathrm{PCP}$ & .002869 & .000610 & - & - \\
\hline $\mathrm{T} \times \mathrm{PCP} \times \mathrm{PCP}$ & -.000048 & .000016 & - & - \\
\hline
\end{tabular}

aParameter estimates for year of birth ranged from -.728 to .818 in the analysis of cows with no dystocia and from -.877 to .853 in the analysis of cows with dystocia.

${ }^{b}$ Age of dam $\times$ birth weight category interaction. Birth weight category is defined in the text. 
and

$$
\hat{P}_{n o \text { dystocia }}=\frac{1}{1+e^{2.843+.053 T-.001 T^{2}-.069 P C P+.001 P C P^{2}+.003 T \times P C P-.00005 T \times P C P^{2}}}
$$

$$
\hat{P}_{\text {dystocia }}=\frac{1}{1+e^{1.312+.011 T-.0006 T^{2}}}
$$

aids in interpreting the effects of the two variables on survival (Figure 2). The isograms of precipitation are only extended over the range of temperature that actually occurred (e.g., $50 \mathrm{~mm}$ of precipitation only occurred between 10 and $24^{\circ} \mathrm{C}$ ). Extrapolation of the functions outside the data range would result in erroneous predictions. When cows experienced dystocia, there was no effect of precipitation on mortality and the effect of temperature was not as large as when cows did not experience dystocia. This difference might also be caused by preferential treatment of the cow-calf pair that required extensive calving assistance.

When cows did not experience dystocia, precipitation had greater effects on mortality at lower temperatures. This is evident if one compares the estimated mortality rates in Figure 2 at for example -6 and $10^{\circ} \mathrm{C}$. This is expected because the amount of precipitation would affect the insulating ability of the hair coat. When precipitation was heavy $(75 \mathrm{~mm})$, mortality increased slightly with temperature. It is possible that this is a spurious relationship due to confounding effects with sources of variation not accounted for in the model.

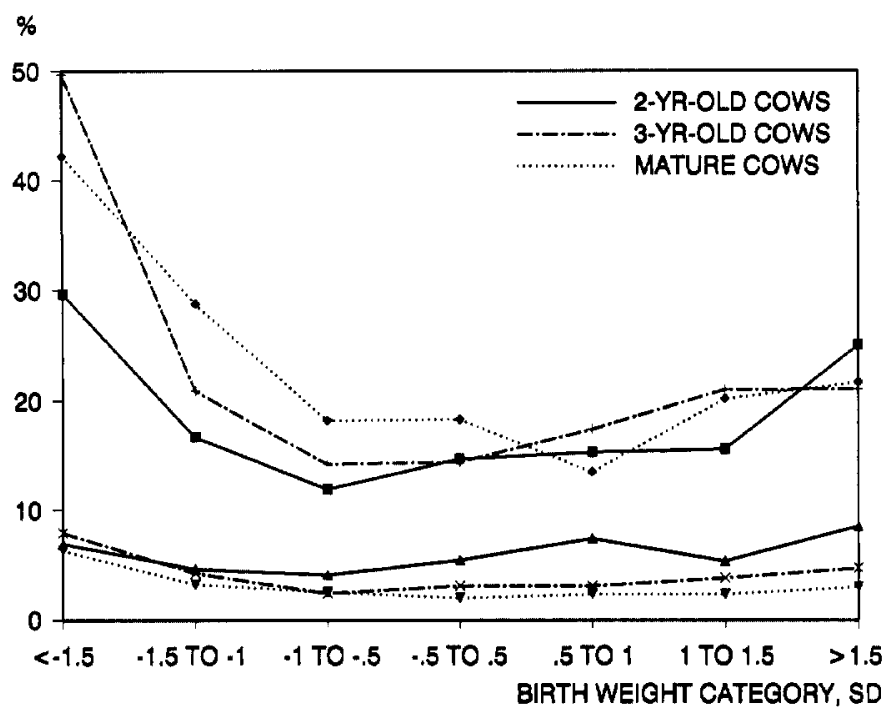

Figure 1. Estimated mortality rates (percentage) for different ages of cows and relative birth weights of calves (SD from the mean birth weight for the sex $\times$ age of dam $\times$ genetic selection line or breed composition sub-category). Upper three lines are for cows experiencing dystocia; lower three lines are for cows with no dystocia.
The relative effect of temperature and precipitation on mortality also depends on the fixed effects in the model (i.e., the intercept in the logistic regression equation). This is depicted in Figure 3 in which the effect of temperature and precipitation on mortality are estimated for two types of calves: 1) a heifer that is > 1.5 SD of average calf size and is born to a 2-yr-old cow without dystocia and 2) a heifer that is of average size and born to a mature cow without dystocia. The intercept (2.843) in [5] is thus replaced by $2.089(2.843+.044-.798$, Table 2$)$ for the first type of calf and by $3.598(2.843+.044+.711$, Table 2$)$ for the second type of calf. Figure 3 shows that precipitation has a greater effect on mortality of calves with higher mean mortality rates (2-yr-old cow, large calf; Figure 1) than on calves with lower mean mortality rates (mature cow, average calf; Figure 1).

Optimal Time of Calving. To study the effects of calving time and age of dam on calf survival, the daily temperatures and precipitations for January to June (Figure 4) were used in [5] (no dystocia). The marginal means of mortality rate (MR) for age of dam were obtained by multiplying the MR for age of dam $\times$ BWT by the expected proportions of calves in each BWT (based on a normal distribution) and summing the products across BWT (Figure 5). The mortality rates for each month were calculated by averaging the daily MR and are also shown in Figure 5. Mortality

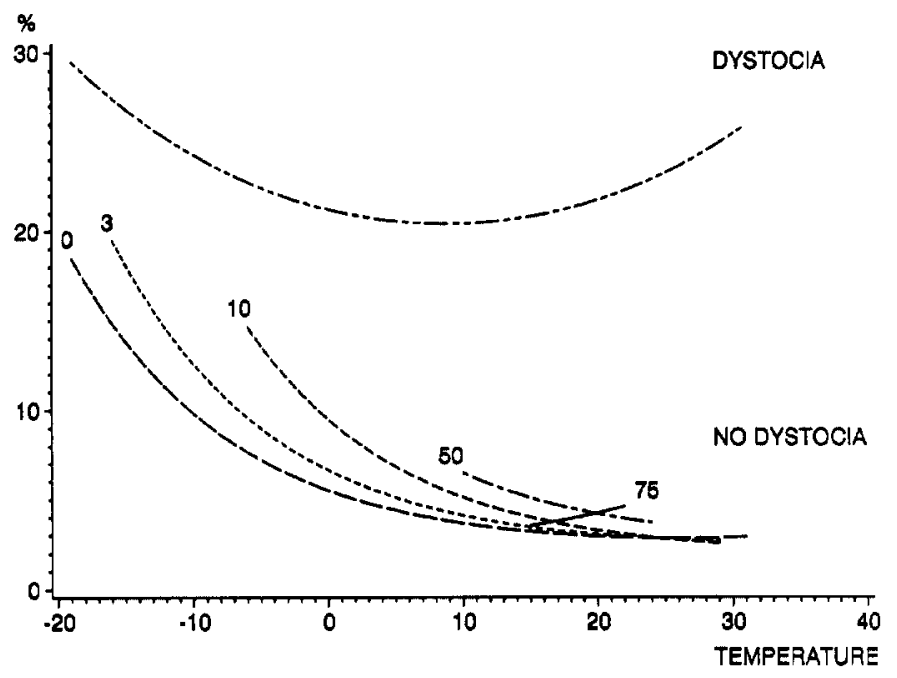

Figure 2. Effects of ambient average temperature $\left({ }^{\circ} \mathrm{C}\right)$ and amount of precipitation $\{0,3,10,50$, and $75 \mathrm{~mm})$ at day of birth on mortality rate (percentage) for calves born with or without dystocia. 


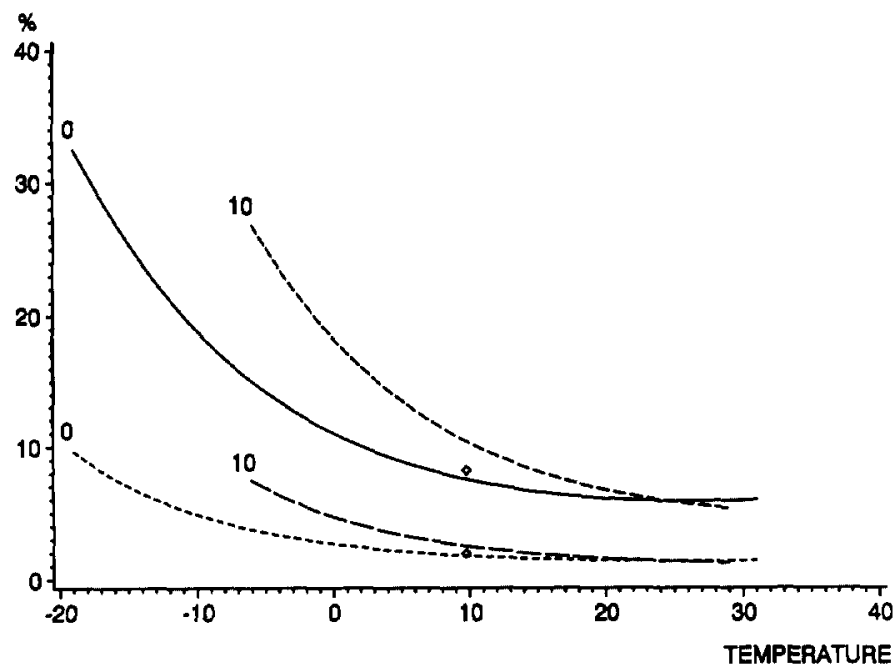

Figure 3. Effects of ambient average temperature $\left({ }^{\circ} \mathrm{C}\right)$ and amount of precipitation $(0$ or $10 \mathrm{~mm}$ ) at day of birth on mortality rate (percentage) for 1) a heifer that is $\geq 1.5$ $\mathrm{SD}$ and is born to a 2-yr-old cow without dystocia (two upper lines) and 2) a heifer that is of average size and is born to a mature cow without dystocia (two lower lines). The marginal means for the two types of calves, adjusted to the average temperature $\left(9.77^{\circ} \mathrm{C}\right)$ and precipitation $(2.35 \mathrm{~mm})$ are also shown (0)

decreased with month of calving (Figure 5). The decrease was largest from January to April with only slightly lower mortality rates in May and June. There was not a large differential effect of calving month on survival between calves born to 3-yr-old and mature cows. However, calves born to 2-yr-old cows were more adversely affected by calving conditions in early spring than were calves born to older cows.

The predictions of mortality only take the weather variables into consideration. Other environmental variables that affect calf survival that might vary with month were not included in the predictions.

\section{Discussion}

Calf survival in influenced by both genetic and environmental factors and could be increased either by exploring and using genetic diversity in tolerance of cold stress or by changing current management strategies. Both approaches need to be considered.

First, genetic selection for survival could be explored. Cundiff et al. (1986) found that heritability of survival to weaning was low with breeds $(6.7 \%)$ but the variation among breeds was great. Cundiff et al. (1982) suggested that selection for survival could be accomplished by including survival related biological components such as cold resistance, immunological factors, skin thickness, and type of birth coat. Selection on any of these traits would be at the expense of selection for other important performance

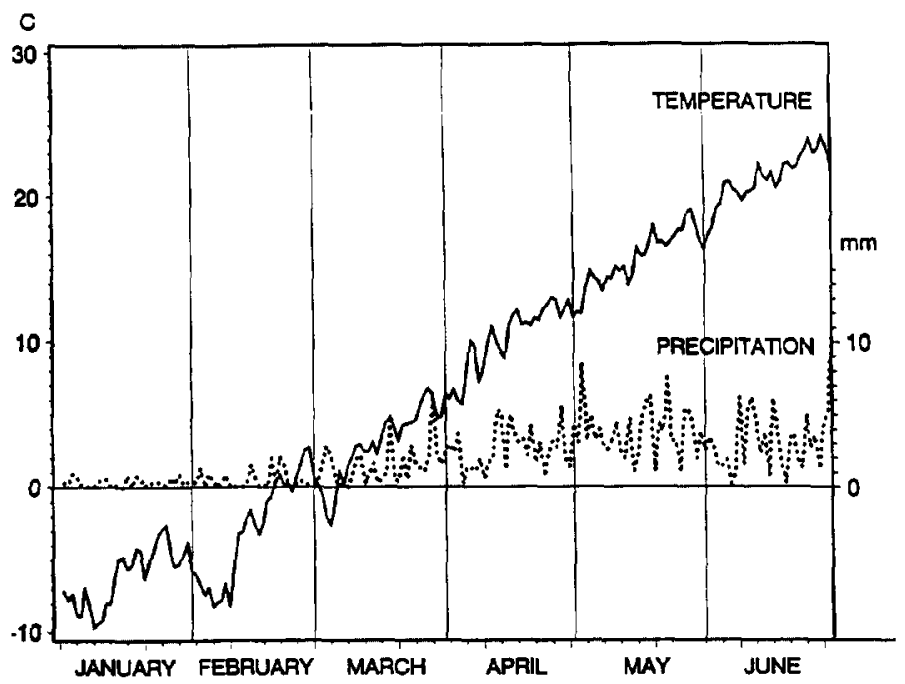

Figure 4. Average ambient temperature and precipitation at Clay Center, NE (1969 to 1989).

traits. Thus, if survival could be optimized by a costeffective change of management, this would be preferable.

Second, neonatal survival could be increased by changing the management of the cow-calf herd. This requires information on the effects of environmental factors on neonatal survival. Many of these are well documented.

The effect of age of dam on neonatal mortality was discussed by Hohenboken et al. (1987) and reported estimates range from 2.5 to $9.2 \%$ in mature cows and from 5.9 to $13.4 \%$ in heifers (Marlow et al., 1984; Morris et al., 1986; Patterson et al., 1987; Ray et al., 1989). Our estimates (weighted and summed over BWT and adjusted to the average temperature and precipitation) for 2-yr-old (heifers), 3-yr-old, and mature cows were $5.7,3.6$, and $2.6 \%$ for cows without dystocia and $16.3,18.8$, and $20.5 \%$ for cows with dystocia, respectively. The incidence of dystocia was $15 \%(11,094 / 72,187)$.

Birth weight has also been linked to mortality (Cundiff et al., 1982; Morris et al., 1986). McElhenney et al. (1986) found that the preweaning mortality of calves sired by large breed bulls was $14.6 \%$ compared with calves sired by bulls of a medium-sized breed $(4.7 \%)$. Koch et al. (1982) also found that calf mortality increased in 2-yr-old cows with selection for growth to weaning or to $1 \mathrm{yr}$ of age. However, Baker and Morris (1984) in a literature review also found selection experiments for growth rate in which no increase in calf mortality occurred. In our study, birth weight per se was not used but rather the relative size of the calf was used. Survival was at an optimum for average-sized or slightly smaller $(-1$ to $-.5 \mathrm{SD})$ calves. This is in agreement with estimates reported by Notter et al. (1978), Morris et al. (1986), and Gregory et al. (1991). 


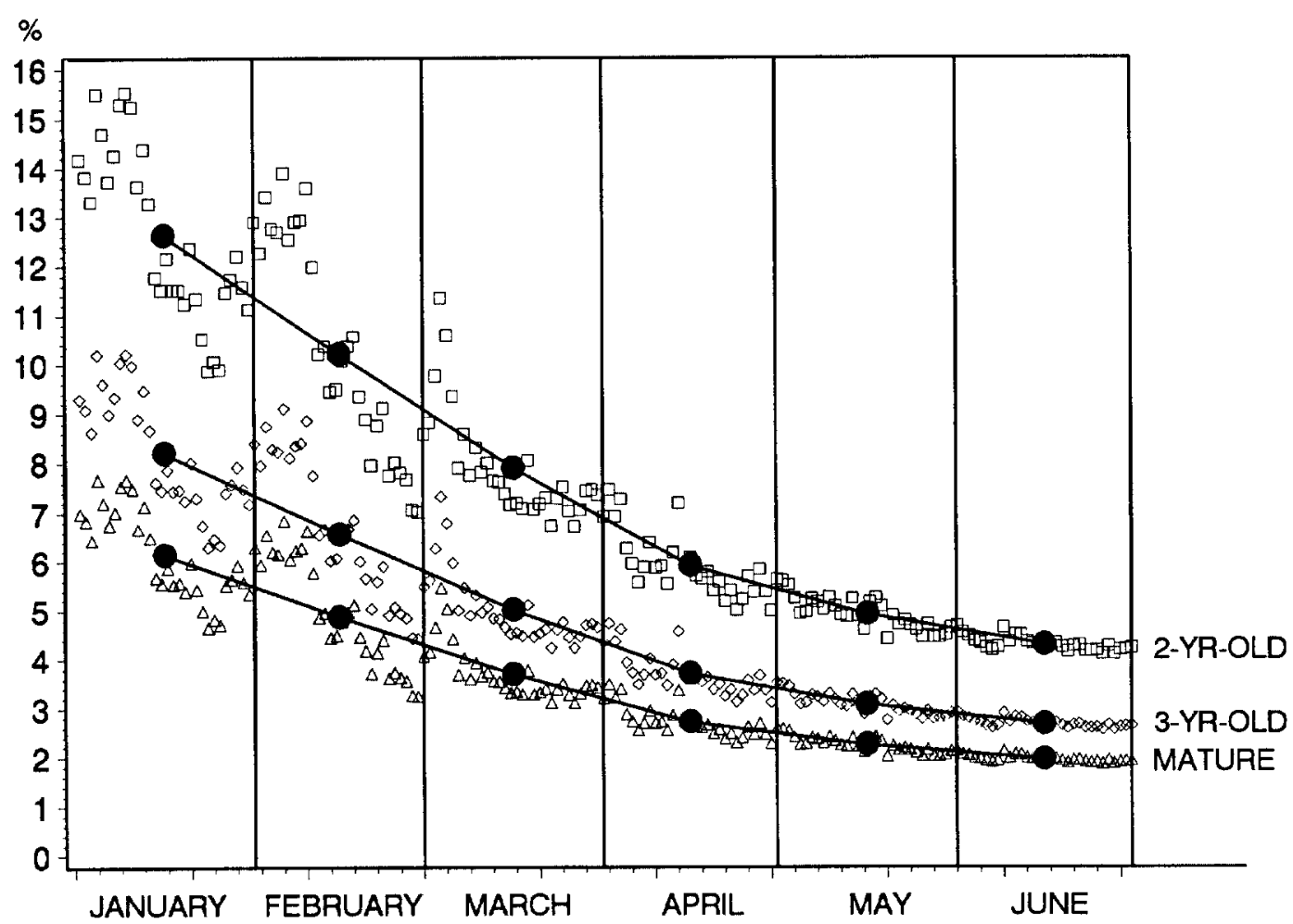

Figure 5. Estimated mortality rates (percentage) for different ages of cows calving during different months (January to June), based on the daily temperatures and precipitations during the given month. Average mortality rate for the month is indicated by $\bullet$.

Dystocia and its effect on calf mortality were studied by Laster and Gregory (1973). They found that the calf was four times as likely to die if the cow experienced dystocia as if she did not. In our study, neonatal mortality in cows that did not experience dystocia was .04, whereas it was .20 in cows that did experience dystocia, resulting in a ratio of five. Patterson et al. (1987) found that $45.9 \%$ of all preweaning deaths resulted from dystocia. In our study, the actual number of calves that died in the nodystocia and dystocia groups were 2,869 and 2,218, respectively, resulting in $43.6 \%$ of all neonatal deaths occurring in calves born to cows experiencing dystocia.

Climatic effects on calf mortality have been reported by Withers (1952) based on analysis of approximately 9,000 dairy and beef calves in Great Britain. The mortality attributed to severe weather was $3.6 \%$. Sparse information is available on the effects of weather-related stress on neonatal survival under range conditions. Bellows et al. (1987) attributed $6.9 \%$ of the mortality in 620 normal calves to exposure (chilling). Manak and Kvasnicka (1982) reported a study on weak calf syndrome in Nebraska where this condition seemed to be associated with weather stress and that an increased frequency of deaths from this syndrome occurred during periods of cold, wet weather. Stanko et al. (1991) found that Brahman calves that were $<24 \mathrm{~h}$ old were less able to cope with cold environmental temperatures than were older calves. Our study shows that the amount of precipitation and the average ambient temperature on the day of birth interact and affect mortality nonlinearly. The magnitude of the effect of climate on neonatal survival depends on age of dam, sex and size of calf, and on dystocia incidence.

Of the many factors affecting neonatal survival, dystocia is the most important. Therefore, research focusing on means of reducing the incidence of dystocia should receive the highest priority. Of particular interest are the reasons for the high mortality rates of small calves born to cows with dystocia. The possibility of endocrine factors responsible for prolonged labor (weak labor) when calves are small, should be given attention in addition to the anatomical factors usually associated with dystocia. Anthony et al. (1986) reported different prepartum hormone levels in cows experiencing dystocia and cows not experiencing dystocia.

Higher mortality rates of small calves occurred in all age groups of cows, whereas large calves only seemed to be a problem in 2-yr-old cows (for which size of calf is defined as being relative to its sex $\times$ age of dam $\times$ genetic composition mean BWT). From a management point of view, selecting bulls that sire large calves should, therefore, only be avoided when used to breed heifers. 
Protecting calves from wet conditions at birth might be cost effective, especially early in spring when temperatures are lower. If this is not possible or feasible, calving later in the spring would increase the survival rate. This is especially true if the replacement rate in the cow herd is high and a relatively large proportion of cows are 2- and 3-yr old at calving. Higher replacement rates would result from short breeding seasons (Azzam et al., 1990; Werth et al., 1991). Therefore, if a shorter breeding season is preferred, it should be initiated later in the summer in order to increase calf survival.

\section{Implications}

Calves born to cows experiencing dystocia were five times as likely to die during the 1st wk of life as calves born without difficulty. Of calves born with difficulty, survival was lowest for those that were small relative to their genetic group, sex, and age of dam. Large calves had increased mortality when born to 2-yr-old dams. Temperature and precipitation affected survival rates nonlinearly and the rates depended on age of dam, sex and size of calf, and dystocia incidence. Calving late in spring, compared with earlier calving, would result in decreased mortality, especially in calves born to 2-yr-old dams.

\section{Literature Cited}

Anthony, R. V., R. A. Bellows, R. E. Short, R. B. Staigmiller, C. C. Kaltenbach, and T. G. Dunn. 1986. Fetal growth of beef calves. I. Effect of prepartum dietary crude protein on birth weight, blood metabolites and steroid hormone concentrations. J. Anim. Sci. $62: 1363$.

Azzam, S. M., J. E. Kinder, and M. K. Nielsen. 1989. Conception rate at first insemination in beef cattle: Effects of season, age and previous reproductive performance. J. Anim. Sci. 67:1405.

Azzam, S. M., J. E. Kinder, and M. K. Nielsen. 1990. Modeling reproductive management systems for beef cattle. Agric. Syst. 34:103.

Baker, R. L., and C. A. Morris, 1984. A review of correlated responses to weight selection in beef cattle under different management and climatic conditions. In: J. H. Hofmeyer and E.H.H. Meyer (Ed.) Proc. 2nd World Congr. on Sheep and Cattle Breeding 1:236.

Bellows, R. A., D. J. Patterson, P. J. Burfening, and D. A. Phelps. 1987. Occurrence of neonatal and postnatal mortality in range beef cattle. II. Factors contributing to calf death. Theriogenology 28:573.

Buchanan, D. S., M. K. Nielsen, R. M. Koch, and L. V. Cundiff. 1982. Selection for growth and muscling score in beef cattle. I. Selection applied. J. Anim. Sci. 55:516.

Cundiff, L. V., and K. E. Gregory. 1982. Genetic variation among and within herds of Angus and Hereford cattle. Beef Res. Program Progress Rep. No. 1, Roman L. Hruska U.S. Meat Anim. Res. Center, USDA ARM-NC-21:16. Clay Center, NE.

Cundiff, L. V., K. E. Gregory, and R. M. Koch. 1982. Selection for increased survival from birth to weaning. Proc. 2nd World Congr. on Genet. Appl. to Livest. Prod. 5:310. Madrid, Spain.

Cundiff, L. V., R. M. Koch, and K. E. Gregory. 1988. Germ plasm evaluation in cattle. Beef Res. Progress Rep. No. 3, Roman L.
Hruska U.S. Meat Anim. Res. Center, USDA ARS-71:3. Clay Center, NE.

Cundiff, L. V., M. D. MacNeil, K. E. Gregory, and R. M. Koch. 1986 Between- and within-breed genetic analysis of calving traits and survival to weaning in beef cattle. J. Anim. Sci. 63:27.

Gregory, K. E., L. V. Cundiff, and R. M. Koch. 1988a. Germ plasm utilization in beef cattle. Beef Res. Progress Rep. No. 3, Roman L. Hruska U.S. Meat Anim. Res. Center, USDA ARS-71:9. Clay Center, NE.

Gregory, K. E., L. V. Cundiff, and R. M. Koch. 1991. Breed effects and heterosis in advanced generations of composite populations for birth weight, birth date, dystocia, and survival as traits of dam in beef cattle. J. Anim. Sci. 69:3574.

Gregory, K. E., L. V. Cundiff, R. M. Koch, D. B. Laster, and G. M. Smith. 1978a. Heterosis and breed maternal and transmitted effects in beef cattle. I. Preweaning traits. J. Anim. Sci. 47: 1031.

Gregory, K. E., L. V. Cundiff, G. M. Smith, D. B. Laster, and H. A. Fitzhugh, Jr. 1978b. Characterization of biological types of cattle-cycle II: I. Birth and weaning traits. J. Anim. Sci. 47: 1022.

Gregory, K. E., S. E. Echternkamp, G. E. Dickerson, L. V. Cundiff, and R. M. Koch. 1988b. Twinning in cattle. Beef Res. Progress Rep. No. 3, Roman L. Hruska U.S. Meat Anim. Res. Center, USDA ARS-71:29. Clay Center, NE.

Gregory, K. E., S. E. Echternkamp, G. E. Dickerson, L. V. Cundiff, R. M. Koch, and L. D. Van Vleck. 1990. Twinning in cattle: III. Effects of twinning on dystocia, reproductive traits, calf survival, calf growth and cow productivity. J. Anim. Sci. 68:3133.

Hohenboken, W. D., G. W. Seifert, and W. J. Aspden. 1987. Genetic and environmental influences on offspring sex ratio and neonatal survival in Bos indicus $\times$ Bos taurus cattle. J. Anim. Breed. Genet. 104:309.

Josey, M. J., L. V. Cundiff, R. M. Koch, K. E. Gregory, and G. L. Hahn. 1987. Mortality and cold tolerance of calves with different proportions of Bos indicus and Bos taurus inheritance. In: Proc. 8th Conf, on Biometerology and Aerobiology of the Am. Meterological Soc. p 334

Koch, R. M., G. E. Dickerson, L. V. Cundiff, and K. E. Gregory. 1985. Heterosis retention in advanced generation Angus-Hereford Crosses. Beef Res. Progress Rep. No. 2, Roman L. Hruska U.S. Meat Anim. Res. Center, USDA ARS-42:15. Clay Center, NE.

Koch, R. M., K. E. Gregory, and L. V. Cundiff. 1982. Critical analyses of selection methods and experiments in beef cattle and consequences upon selection programs applied. Proc. 2nd World Cong. on Genet. Appl. to Livest. Prod. 5:514. Madrid, Spain.

Laster, D. B., and K. E. Gregory. 1973. Factors influencing peri- and early postnatal calf mortality. J. Anim. Sci. 37:1092.

Manak, R. C., and W. G. Kvasnicka. 1982. Preliminary observations on the immune status of newborn normal and weak calf syndrome calves. Beef Res. Program Progress Rep. No. 1, Roman L. Hruska U.S. Meat Anim. Res. Center, USDA ARM-NC- 21: 23. Clay Center, NE.

Marlowe, T. J., D. R. Notter, R. A. Brown, and E. A. Tolley. 1984. Sire breed effects in matings with Angus cows: I. Fertility, calf survival and performance to 18 months. J. Anim. Sci. 59:11.

McElhenney, W. H., C. R. Long, J. F. Baker, and T. C. Cartwright. 1986. Production characters of first generation cows of a fivebreed diallel: Reproduction of mature cows and preweaning performance of calves by two third-breed sires. J. Anim. Sci. 63: 59 .

Morris, C. A., G. L. Bennett, R. L. Baker, and A. H. Carter. 1986. Birth weight, dystocia and calf mortality in some New Zealand beef breeding herds. J. Anim. Sci. 62:327.

Natter, D. R., L. V. Cundiff, G. M. Smith, D. B. Laster, and K. E. Gregory. 1978. Characterization of biological types of cattle. VI. Transmitted and maternal effects on birth and survival traits in progeny of young cows. J. Anim. Sci. 46:892.

Patterson, D. J., R. A. Bellows, P. J. Burfening, and J. B. Carr. 1987. 
Occurrence of neonatal and postnatal mortality in range beef cattle. I. Calf loss incidence from birth to weaning, backward and breech presentations and effects of calf loss on subsequent pregnancy rate of dams. Theriogenology 28:557.

Pindyck, S. R., and D. L. Rubinfeld. 1981. Econometric Methods and Economic Forecasts. p 299. McGraw-Hill Book Co., New York.

Ray, D. E., S. B. Itulya, C. B. Roubicek, and C. R. Benson. 1989. Pregnancy rate, calf mortality and calving date in unsupplemented Hereford range cows. Livest. Prod. Sci. 23:305.

SAS. 1985. SAS User's Guide: Statistics. SAS Inst. Inc., Cary, NC.

Stanko, R. L., M. J. Guthrie, and R. D. Randel. 1991. Response to environmental temperatures in Brahman calves during the first compared to the second day after birth. J. Anim. Sci. 69: 4419.

USDA-ERS. 1989. Livestock and Meat Statistics, 1984-1988. Stat. Bull. No. 784

Werth, L. A., S. M. Pritchard, S. M. Azzam, D. A. Fiske, G. H. Pfeiffer, M. K. Nielsen, and J. E. Kinder. 1991. Evaluating net income from different durations of breeding seasons in beef production using a deterministic simulation model. Agric. Syst. 37:275.

Withers, F. W. 1952. Mortality rates and disease incidence in calves in relation to feeding, management and other environmental factors, part II. Br. Vet. J. 108:382. 